\title{
Article
}

\section{Material Provocations in the Archives}

\author{
Dani Stuchel
}

\section{ABSTRACT}

As a name, "Anthropocene" would seem to signal that this geologic epoch is both because of humans and about humans. The latter implication draws on pervasive cultural ideas about nature which underlie the Anthropocene and its climatic impacts, namely nature as an extractable, endlessly-renewable resource. While scholars in the environmental humanities, animal studies, and critical plant studies have been quick to both diagnose and propose new directions for our engagements with the material universe, scholarship on archival materiality has continued to focus on the archives as an institution for and about human intellectual endeavors. In other words, the archives continue to be an extractable resource. Within the archives, animal, plant, and abiotic changes which work against projects of human history are seen as failures, infestations, or disasters - they can never be properly archival. This essay offers a potential corrective to anthropocentric archiving, by bringing together Jane Bennett's new materialist project of "vibrant matter," Michael Marder's vegetal philosophy, and Caitlin DeSilvey's curation of decay to suggest avenues of engaging archival materiality as meaningful and provocative. As an analytic schema, this focus on the "vibrant archives" does not aim to save records from planetary changes but to begin the work of re-thinking archival materiality (and its destruction) within the context of the Anthropocene. 


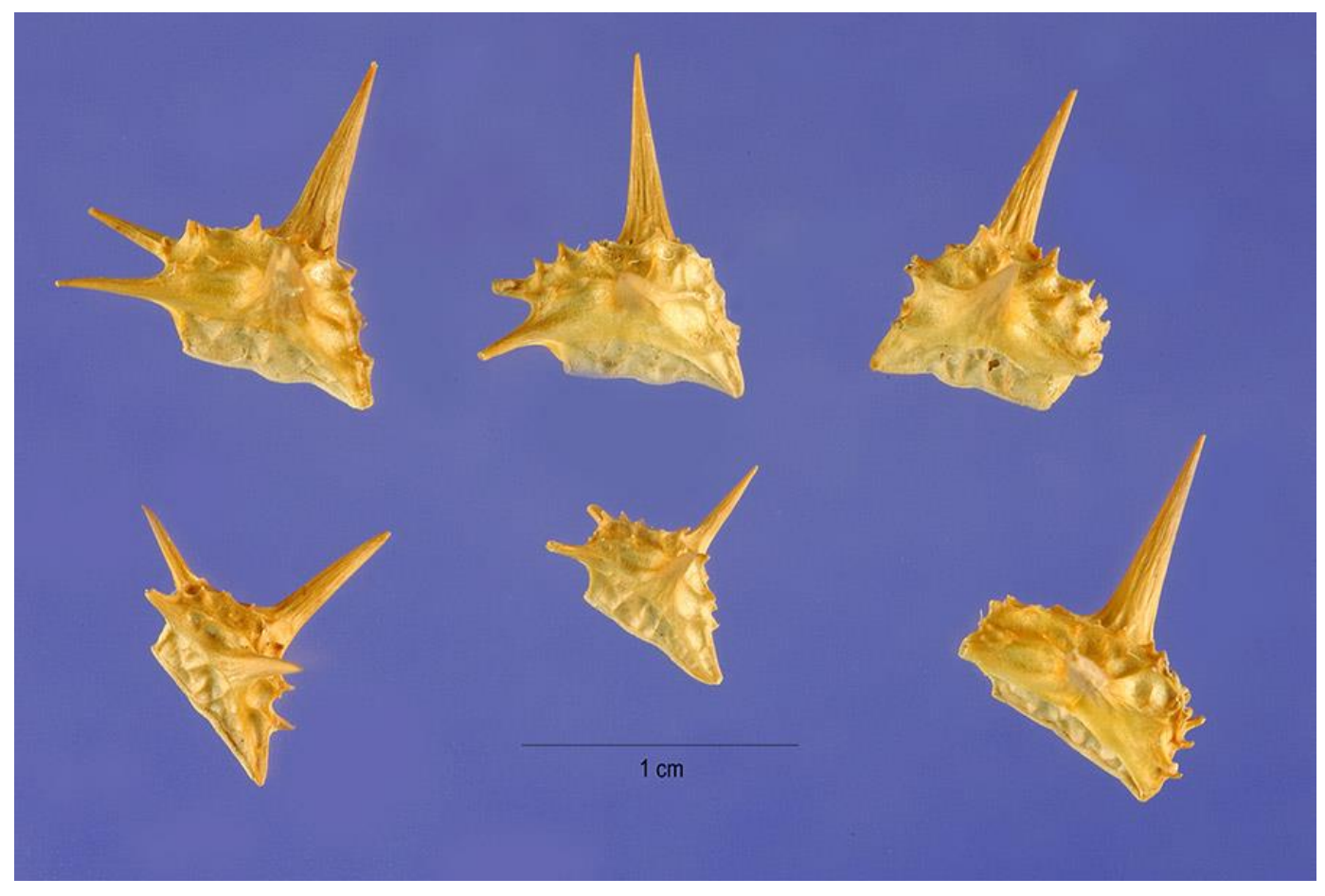

Image 1. Fruit of the Tribulus terrestris plant. Photograph by Steve Hurst.

\section{INTRODUCTION}

Standing in the elevator which links the University of Arizona's Special Collections storage facility to its reading room, I looked down at the skin of my hands as they reflected back the clinical glow of fluorescent bulbs. My left hand applied palpating pressure to my right while my eyes traced out the movements - eyes and fingers working in tandem to map out the origin of pain. Days earlier, I had retrieved the fruit of a puncture vine - Tribulus terrestris - from the back of my shoe. A pebble-sized, hard-shelled nut, the fruit of the plant has two sharp prongs - earning it the nickname "goat's head." Tribulus performed its namesake in two iterations: once on my ankle, once on my investigative fingers. The latter injury came as I fished Tribulus out of my shoe and threw it curbside. Content to have dislodged the fruit from my person, I hurried towards the bus stop and presumed the encounter complete. Now, days later, I squinted to clarify a vague contrastive mass under skin desiccated by the dust of early $20^{\text {th }}$ century financial ledgers. The ledgers were unwieldy sizes and always interleaved with an impossibly dry dust. My fingers were reshaped by the dust, with curvilinear flakes reaching away from the surface of my body and catching nearby fibers. As my skin began to crack, touch became synonymous with soreness. The archives was changing my body. Now it appeared that Tribulus was present, too, with part of its goat-like thorns stored in my own surface. Rather than a master 
organizer, an inscriber of meaning, I - the archivist - had become a locus of nonhuman action and the storing of vegetal meaning.

The term "Anthropocene" starts with a double problem: anthropos. It is in and through the Anthropocene that we have come to terms with the immense impact humans make in the ecologies of this planet. Many of us now recognize that colonial and capitalist structures of resource extraction and commercial production are destructive on a global scale. We recognize that we are not a narrative center around which the rest of the planet simply organizes, but instead part of complex ecologies which change along, against, and through us. As it turns out, the earth does not exist for us and we are the problem.

At the same time, "Anthropocene" invokes anthropos, the not-Self studied in anthropology and anthropometrics, differentiated from the homo Self of humanity. ${ }^{1}$ It is forever the humans of the past, or the capitalist regime as an abstract thing, which brought us into the Anthropocene - not me. In a moment of planetary crisis, we name this era after something like ourselves, but not quite ourselves. The second problem with "Anthropocene," then, is its ability to create a fictitious subject who knows the Anthropocene but who is not responsible for its emergence and development. That subject then becomes the narrative center of experiencing the Anthropocene, displacing the animal, plant, and abiotic entities at play on our planet.

This is no less true in the archives. While recent literature in archival studies has explored avenues by which physical and digital repositories might mitigate or adapt to the climactic aspects of the Anthropocene, ${ }^{2}$ we have been slow to let the Anthropocene alter our focus on the archives as a human institution about human histories. As a possible redirect, this essay will argue that we can think of archives as agential material assemblages characterized as much by the actions of dust, moisture, and plant matter as they are by human records and labor. Rather than expecting archival things to conform to archival concepts, this essay traces the frustrating and resistant materiality of the archives. ${ }^{3}$ Within this essay, I want to position the Anthropocene as an outgrowth of the material possibilities archivists have long ignored. Rather than a condition to be cured by "going green," the Anthropocene is a symptom, a pathologization of materiality, a diagnosis. In response, I contend that archives of the Anthropocene must take matter

1 Phillip John Usher, “Untranslating the Anthropocene," Diacritics 44, no. 3 (2016): 56-77.

2 Recent scholarship discussing archives and libraries within the Anthropocene includes Eira Tansey, "Archival Adaptation to Climate Change," Sustainability: Science, Practice and Policy 11, no. 2 (2015): 45-56; Mark Wolfe, “Beyond 'Green Buildings': Exploring the Effects of Jevon's Paradox on the Sustainability of Archival Practices," Archival Science 12, no. 1 (2012): 35-50.

3 Amelia Acker's writing on cell cultures provides an example of archival scholarship which both inscribes archival concepts onto biological material while noting the challenges inherent in doing so. See Amelia Acker, "How Cells Became Records: Standardization and Infrastructure in Tissue Culture," Archival Science 15, no. 1 (2015): 1-24. 
seriously and form, "a totally different way of understanding the relationship between humans, technologies, cultures and the rest of the natural world." 4

As the collecting scope of archives shifted in the late twentieth century to contain more than bureaucratic reports and corporate papers, our repositories revealed themselves to be effused with personal traumas, ${ }^{5}$ queer feelings, ${ }^{6}$ and other forms of matter and memory which resist a straightforward utility. These psychic specters and confounding objects push us back towards theory, towards introspection on what it means to archive and on the psychological impulses which drive our need to keep, evince, retrieve, and preserve. Tribulus' thorn, lodged almost invisibly under my skin, provided one such push. Through its irritating presence, my attention was drawn to matter in the archive which slips through the meaning-making nets of history, provenance, controlled vocabularies, space calculations, and processing workflows. By evading the nets, Tribulus appears a "meaningless" distraction from the important work of archiving: lingering on dust is a waste of company time. In this essay, I will demonstrate that new materialism and critical plant studies offer promising tools for thinking through such odd archival encounters. New materialism often utilizes lessons from science, critiqued through science studies and feminist studies, to inquire about the being or becoming of material things - humans included. Critical plant studies revisits long-foreclosed debates around the meaning of plant existence and deconstructs Western philosophy's treatment of plants and our own relationships with vegetal beings. It is obvious that plants have a footprint in the archives - from our acid-free paper products, to the fossil fuels keeping our computers alight, to the food we consume to keep our own bodies in motion. However, it is plants' lack of a purpose (telos) and their curious manner of enmeshing themselves into the world which provide new starting points for theorizing the materiality of archival objects.

More than a thought experiment, approaching archives in the Anthropocene with new analytic tools will prepare us to tackle coming ideological hurdles. ${ }^{7}$ How do we cope with the sobering fact that the archives' holdings will not save themselves from flood or wildfire, nor will they uphold our need for history or narrative? What meaning, if any, can we find in the indifference of archival matter towards human aims? As repository losses mount, how can we work through the very human feelings which archival decay and rot

4 Whitney Bauman, "Climate Weirding and the Queering of Nature: Getting Beyond the Anthropocene," Religions 6, no. 2 (2015): 742-754.

5 Ann Cvetkovich, An Archive of Feelings: Trauma, Sexuality, and Lesbian Public Cultures (Durham, NC: Duke University Press, 2003).

6 Marika Cifor, "Affect Relations: Introducing Affect Theory to Archival Discourse," Archival Science 16, no. 1 (2016): 7-31.

7 As Anthony Veerkamp notes, we can no longer speak of stopping climate change but rather how to live in it. See Anthony Veerkamp, "Preservation in a Changing Climate: Time to Pick Up the Tab," Forum Journal 29, no. 4 (2015): 9-18. 
provokes? This essay offers beginning points for considering archival materiality in an era of material change and unrest.

\section{ARCHIVAL MATTER}

Archivists have long been aware of the archives' materiality. Indeed, for those of us who physically process collections, there is no question about the physical weight and movement of the archives. Beyond processing, the fields of conservation and preservation consistently attend to the chemical and physical exigencies of archival things. ${ }^{8}$ Within the past four decades, born-digital and digitized records have provoked new questions about the relationship between "physical" materials and their digital correlates, ${ }^{9}$ digitization's relationship to provenance, ${ }^{10}$ and the value of physically engaging with "real" materials. ${ }^{11}$ Responding to increased digitization of archival photographs, Ala Rekrut offers that, "archivists and users of archives can benefit from a greater awareness of materiality and from developing 'material literacy' skills [...]"12 For Rekrut, digital surrogates are important to access, but they cannot replace the nontextual, non-pictorial information about a thing's use and circulation present in cropped edges and creases. Maryanne Dever asks us to push beyond the textual and the pictorial to see archival documents as "work[s] of physical and not simply intellectual composition." ${ }^{13}$ Researchers and archivists alike lose out by seeing a document as

8 Throughout this essay, I will use "archival things" in place of "archival objects" or "archival materials." While the term "thing" has its own baggage, "object" would seem to imply an object-subject relationship which is at odds with the current project. Similarly, "materials" reinforces a view of archival matter-as-utility and makes it difficult to glimpse archival possibilities beyond human intentions. "Thing," perhaps because of its baggage, can provide a sense of the surprising, the non-utilitarian, the ontologically resistant.

9 Jefferson Bailey's history of fonds and its connection to the complex storage of digital records gives consideration to the ways digital records trouble facile notions of "the record." Jefferson Bailey, "Disrespect des Fonds: Rethinking Arrangement and Description in Born-Digital Archives," Archive Journal (Summer 2013). http://www.archivejournal.net/issue/3/archivesremixed/disrespect-des-fonds-rethinking-arrangement-and-description-in-born-digitalarchives/.

${ }^{10}$ See Paul Conway's discussion on the provenance of digitized and re-digitized books in Paul Conway, "Digital Transformations and the Archival Nature of Surrogates," Archival Science 15, no.1 (2015): 51-69.

11 Nina Lager Vestberg, “Archival Value,” Photographies 1, no. 1 (2008): 49-65.

${ }^{12}$ Ala Rekrut, "Matters of Substance: Materiality and Meaning in Historical Records and their Digital Images," Archives and Manuscripts 42, no. 3 (2014): 238.

13 Maryanne Dever, "Provocations on the Pleasure of Archived Paper," Archives and Manuscripts 41, no.3 (2013): 179. 
meaningful text on a substrate of meaningless paper. In the archival records of Australian author Eve Langley, Dever reads the presence of crowded, messy paper as indicative of Langley's fascination with arranging words onto the page. For Langley, "the page is always present[...]" and Langley's use of physical space, not just the text by which she accomplishes that use, is meaningful. ${ }^{14}$ While Dever focuses on the myriad contributions of humans to an archival composition, she also notes the influence water and mold can have on such a composition - influences which are pertinent to understanding archival materiality.

Rekrut and Dever's forays into the materialiality of archives provide a number of important observations. First, if the archives are repositories of information, then we must recognize that not all information is textual or graphic. Second, not all agents or entities responsible for material changes in the archive are human. Third, following Dever, we can think of archival things as compositions - or, as I will call them, assemblages ${ }^{15}$ formed and altered through material contact as well as archival context.

While Rekrut and Dever concern themselves with digitization of analog "things," we can also apply a materialist lens to born-digital records. In their creation and preservation, digital records are materially diffuse (stored on remote computers, changed and transmitted across long physical networks) and impactful (mining of minerals for components, slow decay of technology in landfills). As Ben Goldman highlights, digital records are energy-intensive and we rely heavily on water and fossil fuel to maintain our access to them. ${ }^{16}$ It is this reliance on biotic and abiotic matter which leads Bethany Nowviskie to suggest that the extinction of human and nonhuman lives in the Anthropocene is an undercurrent of digital humanities. ${ }^{17}$ While diffusion makes materiality more difficult to perceive, tracing the materiality of digital records as Goldman and Nowviskie do indicates that digital records - rather than a salvation from the ecotroubles of the physical world - are a reorganization of the same kinds of matter we find

\footnotetext{
14 Ibid., 178

15 I use the term "assemblages" rather than "compositions" to highlight that these aggregates of things are not unified under a totalizing moniker as a title brings together the pages of a book into a composition. Compositions are generally thought to be constituted by parts who derive their meaning from unity in a greater whole. By contrast, assemblages are contingent, situational combinations of things - things which, in the un-assembled state - are still meaningful and not wanting for a culminating purpose. This usage echoes, in part, Jane Bennett's use of the term.

${ }^{16}$ Ben Goldman, "It's Not Easy Being Green(e): Digital Preservation in the Age of Climate Change," Archival Values: Essays in Honor of Mark Greene (Chicago, IL: Society of American Archivists, Forthcoming). Accessed from https://scholarsphere.psu.edu/concern/generic_works/bvq27zn11p.

${ }^{17}$ Bethany Nowviskie, "Digital Humanities in the Anthropocene," Digital Scholarship in the Humanities 30, no. 1 (2015): i4-i15.
} 
in photographs, ledgers, and audiocassettes. For brevity's sake, I will focus on analog records in this essay, but I hope readers will keep in mind the materiality of digital records as well.

With these observations in mind, new materialist thought asks whether the materiality of archival things is qualitatively different from our own materiality and encourages us to read the complexity ascribed to biological lives - animal, plant, fungal, etc. - back into the physical mattering of the archives. ${ }^{18} \mathrm{New}$ materialism can be understood as "a response to and means to contend critically with evolving and emerging understandings and forms of materiality..., an approach to relations that defy textual representation." ${ }^{19}$ In short, the many fractious theories within new materialism work through scientific discoveries about matter, its becomings, and its undoings, and bring those discoveries to work for philosophical and critical aims. Rather than existing as static, discrete entities, material things - including humans - can be thought of as contingent, vibrating, and/or highly local. For Marika Cifor, feminist new materialist scholarship offers methods of attending to the body and its affects, defying the archives' hegemonic reliance on text and language. In this essay, I take up Cifor's call for "scholarly engagement with the materiality of archival space, ${ }^{\prime 20}$ but I shift the discussion slightly: away from narratives with the archivist as the central maker of meaning, towards the archivist as a fecund middle-ground, both agential and acted upon.

\section{A VIBRANT ARCHIVAL THING}

Among institutional archives' many functions, being a resource for retrieval is quite central. If simply retaining archival things sufficed, we could pour them in caskets, shove the caskets in mausoleums, and call the task complete. Instead, we organize archival things and describe them to facilitate retrieval. While this is certainly obvious to any reader, the point is worth belaboring here: a central function of archival repositories is the engagement between things and people on an "uneven playing field" of resource and

\footnotetext{
${ }^{18}$ Reading the complexity of biological life onto the physical matter of the archive does not necessitate believing that archival things are identical to biological entities. Instead, this is an imaginative practice of allowing the complexity we offer plants and animals - in narration especially - to be ascribed to archival things. This is a suspension of disbelief, rather than a declaration of what life must look like.

${ }^{19}$ Marika Cifor, "Stains and Remains: Liveliness, Materiality, and the Archival Lives of Queer Bodies," Australian Feminist Studies 32, nos. 91-92 (2017): 6.

20 lbid., 18.
} 
resource-seeker. ${ }^{21}$ The archives is necessarily a contact zone ${ }^{22}$ with politics of engagement and power. For instance, we do not expect archival things to access us, to engage with us as we engage with them. Archivists help researchers find what they need among the things and "ensure availability," but archivists do not ensure the availability of researchers to things. ${ }^{23}$ From this uneven field emerges a relationship of archival thingsas-resources to be gathered and transmuted through research. The ubiquitous phrase "information resources" is perhaps clear enough evidence that archival things are in the resource class: sought out, extractable, immanent, waiting to be subjected to human will.

An unpleasant parallel to the information resource is the natural resource: the sought out, extractable, subject-to-human-desire biomass and "geomass" which constitutes our planet. Michael Marder links our concept of planet-as-resource, and more specifically plants-as-resources, to an Aristotelian metaphysics wherein plants, possessing only a vegetal sou ${ }^{24}$ characterized by endless proliferation, are provided with meaning through human utility. ${ }^{25}$ In this framework, the extraction of plant material for human use is not only indicative of humans succeeding in their role in the universe but also entirely unproblematic - plants are expected to forever restore what we take. Over the past two centuries, crop failures resulting from global climate change and the decimation of plant species through pollution and habitat destruction ${ }^{26}$ have emerged as startling

${ }^{21}$ I am not suggesting that humans and things are categories which must be mutually exclusive, but in this discussion it is worthwhile to point out the loci of power and action in this relationship. Even if people are a kind of "thing," it is our kind of thing which seems to impinge on the agency of other things - archival, planetary, etc. - in particular ways. Archival materials do access us, I would argue, even if we refuse to acknowledge it and this essay aims to trace how we are accessed.

${ }^{22}$ A contact zone, following Donna Haraway, is the place wherein sets of material relationships encounter one another, are changed through the encounter, and generate new sets of relationships. This is necessarily a contact which changes all involved. See Donna Haraway, When Species Meet (Minneapolis, MN: University of Minnesota Press, 2008): 216-218.

${ }^{23}$ Society of American Archivists, "What are Archives?" 2015, https://www2.archivists.org/about-archives.

${ }^{24}$ Here, soul should be understood as the Greek psukhê, an internal force which impels an organism to grow and change rather than an essential quality which provides an entity with its central identity. In contemporary terms, we might think of psukhê as the force which prompts cells to divide.

25 Michael Marder, "On Lack and Plenitude in the Vegetal World," (Keynote address, Plantarium: Re-Imagining Green Futures, Linköping University, Sweden, June 1, 2017.) Retrieved from http://www.totuusradio.fi/wordpress/wp-content/uploads/2017/10/marder075.mp3 (accessed March 9, 2019).

${ }^{26}$ Bjorn Lomberg's discussion of biodiversity demonstrates how vegetal extinction, while an ongoing and real concern, should be looked at critically. See Bjorn Lomberg, "Biodiversity," in 
contradictions to Aristotle's conception of the plant-as-resource. Climatic effects of fossil fuels, largely comprised of fossilized plant life, demonstrate the trouble with seeing plant life as solely a resource to be used. Thus, within the Anthropocene, the re-consideration of resource relationships - including archival things-as-resources - is imperative.

Experimenting away from the Aristolean unidirectional rapport, Jane Bennett gives serious thought to things as agents and works to trouble the boundaries between us/them, alive/dead, human/thing. Bennett's "vibrant materialism" traces an active engagement of things ordinarily considered inert and theorizes this engagement as the result of a vibrancy inherent to matter. ${ }^{27}$ For Bennett, all things have vibrancy - a capacity to engage with and influence - but not all vibrancy is configured identically. Differences are qualitative rather than quantitative, such that the vibrancy of a bird and the vibrancy of a pencil are not in a less-than/more-than relationship. This does not erase difference, but it does attempt to forestall the creation of a hierarchy of living things. ${ }^{28}$ Her example par excellence is the power grid, whose failure can be understood as the unfolding of many agential possibilities - especially electricity's surprising ability to "reverse directions" and flow in a loop - realized through both the decay of the physical grid and the greedy governance of federal politicians. ${ }^{29}$ While there are many theories on the power and agency of things, Bennett's focus on the formation of vibrant assemblages contingent, often temporary, combinations of vibrant matter which result in new possibilities of engagement - make her concept of "vibrant materialism" particularly apt to the archives. As Tom Roberts writes, "Bennett focuses on the latitudinal capacities for individuals to enter into new ecologies that unfold unforeseen capacities." ${ }^{30}$ All things have vibrancy, and vibrancy imparts to all things the possibility of effecting change in the world, but some possibilities only render themselves in the context of other vibrant things, other agencies. In archival parlance, we might say that Bennett is considering the agency of things as it is made manifest through context. Just as the traditional archival meaning of a document is made possible through the context of the fonds and

The Skeptical Environmentalist: Measuring the Real Estate of the World (Cambridge, UK: Cambridge University Press, 2004): 247-257.

27 Janet Bennett, Vibrant Matter: A Political Ecology of Things (Durham, NC: Duke University Press, 2010).

${ }^{28}$ Bennett is quick to point out the fascist, genocidal history of understanding some people as "less alive" than others. Thus, vibrant materialism strives to recognize difference without engaging in a vertical organization of vibrancies whereby some things and assemblages (people included) become less meaningful, less worthy of existence than others.

${ }^{29}$ Ibid., 27.

${ }^{30}$ Tom Roberts, "From 'New Materialism' to 'Machinic Assemblage': Agency and Affect in IKEA," Environment and Planning A 44, no. 10 (2012): 2516. 
provenance, ${ }^{31}$ so things can be understood to have agency which is unfolded or unfurled in the context of other things.

The unfolding of archival vibrancy can be frustrating. During the fall of 2017, I processed the Joe Carithers Papers as a graduate assistant at the University of Arizona Special Collections Library, a collection of approximately nine linear feet containing correspondence, manuscripts, and photographs. ${ }^{32}$ Joe Carithers was a lifelong naturalist and advocate of the National Parks system in the United States. Among his papers were hundreds of film negatives and contact prints from his visits to national parks and wildlife areas. The archival things in the collection had travelled with Carithers and his family throughout his lifetime, and after his death in 2001. Over the many years, these things were in contact with moisture, insects, fungal spores, sunlight, and heat. In one or two instances, the contact prints had been stored with the image sides pressed together underneath stacks of paper, photo albums, or books. As a result, pairs of images had become physically enmeshed - the silver albumen emulsions blending into one another, disrupting a stream of otherwise individual loose photographs. They had become an assemblage comprised of entities which had once been perceived as discrete.

Though the practical archivist might discuss possible methods of conservation and restoration, describe their own course of action, and reflect on the results, I would like to put aside the question of "What do we do?" to ask "What can we learn by meditating on this material assemblage?" A few suggestions: First, we are looking at a manifestation of the photos' possibilities which have overflowed human intentions for the photographs. While we create photos with the intention of keeping them separate, given a favorable environment two photographs will stick to one another. The photograph's materiality contains possibilities which trouble our aims just as much as they fulfill them. The assemblage of sticky photos is formed through the unfolded material possibilities of two things within a "favorable" context for such unfolding. Second, even if the photos were "unstuck," they could be seen as material assemblages comprised of tree pulp or cotton, silver nitrate, albumen, gelatin, and other biotic and abiotic matter. Within these components, electrons may live bewildering lives of self-creation and selfannihilation while chemical interactions unfold. ${ }^{33}$ The appearance of a photograph as a

${ }^{31}$ Luciana Duranti's criticisms of archival appraisal provide a strong example of this line of thought wherein a document cannot maintain its archival meaning without its archival context. See Luciana Duranti. 1994, "The Concept of Appraisal and Archival Theory," The American Archivist 57, no 2 (1994): 328-344.

32 Joe Carithers Papers, 1909-2001 (MS 600), Special Collections, University of Arizona Libraries.

${ }^{33}$ Karen Barad's discussion of lightning and transmaterialities helpfully elucidates the "promiscuity" of matter. See Karen Barad, "TransMaterialities: Trans*/Matter/Realities and Queer Political Imaginings," GLQ: A Journal of Gay and Lesbian Studies 21, nos. 2-3 (2015): 387422. 
static, whole thing is belied by the "contingency and porosity of bounded structures, ... [the] unavoidable implication within wider assemblages of shifting molecular flows." ${ }^{34}$

Provenance is invoked in these observations, as we attend to the multiple forces which shaped this assemblage. Within this vibrant archive, the diffuse agency which results in material changes is resistant to the tradition of identifying a singular creator or a coherent set of human creators and necessitates looking across species boundaries and categories of alive/not alive to fully grasp the provenance of a thing. Carithers and his family were responsible for packing (and likely unpacking/repacking) the materials over time, possibilities of action which are proper to humans. Furthermore, the nonhumans ${ }^{35}$ involved - the components making up the photographs, surrounding documents, humidity, sunlight - unfolded their possibilities into the mix, rendering the photos fused. Tom Nesmith's concept of societal provenance is one example of diffuse agency already under consideration in archival studies. ${ }^{36}$ Nesmith describes the social forces which make record creation, retention, and circulation possible, and offers that all these forces must be considered part of a record's provenance. I argue that material and social possibilities are co-operative, meaning they operate alongside and through one another. As Nesmith suggests, social conditions determine the material forms we choose for the creation of records. Simultaneously, the materiality of those archival things determine what kinds of physical assemblages might emerge and the social events or responses those assemblages might provoke. Provenance and creatorship are forever re-negotiated within the vibrant archives, always in flux.

\section{PURPOSE \& MEANING}

By letting vibrancy problematize anthropocentric concepts of provenance and context, we are able to also inquire about other-than-human interpretations of archival assemblages. Had Joe Carithers glued his photographs together we would certainly consider the act of sticking, the resulting assemblage, and its placement in the overall collection to be significant to archivists and researchers alike. If environmental conditions, the weight of surrounding things, and photographic materialities are, alongside humans, legitimate creators of the resulting sticky assemblage, then our understanding of the

\footnotetext{
${ }^{34}$ Roberts, "From 'New Materalism',"2515.

35 Throughout this essay, I use "nonhuman," "more-than-human," and "other-than-human" interchangeably. Each term highlights and obscures aspects of photographic or plant existence. By moving between the terms, I hope to alternate vantage points and demonstrate the many ways we can perceive these entities.

${ }^{36}$ Tom Nesmith, "The Concept of Societal Provenance and Records of Nineteenth-Century Aboriginal-European Relations in Western Canada: Implications for Archival Theory and Practice," Archival Science 6, nos. 3-4 (2006): 351-360.
} 
assemblage's meaning must expand beyond the documentation of human history. This is not to suggest that we can reliably access the meaning of the sticky photo assemblage for the sticky photo assemblage. Instead, wondering about nonhuman meanings is an analytic tactic for imagining archival meanings without giving undue weight to pragmatic human interests. Perhaps there is no meaning of the assemblage for the assemblage, but by imagining what meanings there could be, we begin to take note of the other-thanhuman existences which populate our repositories. If the world is not for us, perhaps the archives is not either.

Giving consideration to the many meanings in materially heterogenous archives will necessitate multiple theoretical approaches. Returning to the Tribulus thorn embedded in my finger, I ask: What can theories of plant life tell us about the archives? As mentioned earlier, plant matter is ubiquitous in the archives but its "plantness" often goes unconsidered. Critical plant studies provide useful concepts for thinking capaciously through the meaning and change of plants, which in turn can help us reconsider the materiality of archival things in assemblages. Critical plant studies is an emerging field of scholarship which attends to what the popular press might call "the hidden life of plants." With strong ties to animal studies and the deconstructionist philosophies of Jacques Derrida, Gilles Deleuze, and Felix Guattari, plant studies revives long-ignored, or longdeferred, questions about the state of plant existence, vegetal means of sensation and communication, and the ethics of human-vegetal engagement. ${ }^{37} \mathrm{~A}$ particularly clarion voice in the critical plant studies literature is that of philosopher Michael Marder, whose monograph Plant Thinking: A Philosophy of Vegetal Life addresses the question of the plant's soul in the Greek philosophical sense of psukhê, a force which impels an entity to grow and change. ${ }^{38}$. For Aristotle, the plant psukhê was that of proliferation and growth - uncontrolled, untamed. To be a plant is to grow whenever possible, with no restraint: monstrous. This lack of restraint was connected to the plant's lack of telos - of a culminating purpose or endpoint. Aristotle also associated plants with their lack of bodily

37 Though still young, the field of critical plant studies has produced a wealth of literature in the past decade. A few central texts in the field include Michael Marder and Mathilde Roussel's The Philosopher's Plant: An Intellectual Herbarium (New York: Columbia University Press, 2014); Patricia Vieira, Monica Gagliano, and John Ryan's The Language of Plants: Science, Philosophy, and Literature (Minneapolis, MN: University of Minneapolis Press, 2017); and Matthew Hall's Plants as Persons: A Philosophical Botany (Albany, NY: SUNY Press, 2011). For a comprehensive, ongoing bibliography of critical plant studies literature, see "Bibliography," Literary and Critical Plant Studies Network, https://plants.sites.arizona.edu/content/8 (accessed December 12, 2018).

38 Michael Marder, Plant-Thinking: A Philosophy of Vegetal Life (New York: Columbia University Press, 2013). 
interiority, lack of visible breath, and the hidden workings of the internal organs. ${ }^{39}$ The plant is exteriority in excess, a surplus of surface ever striving to touch soil and sunlight, but without a subliminating internal mystery. Lacking a telos and a proper interiority, plants do not form subjectivity through transcendence or resurgence of the Self in the internalizing of the Other. Instead, through their prolific exteriority, plants' becoming is accomplished through ongoing physical contact with solar radiation. Marder argues that plant-time, a conception of time proper to plant life, is in fact the time of soil, the sun, and commercial agriculture. This is a subjectivity without identity.

Though humans are, in the lineage Marder traces, seen as possessing something of the plant psukhê which drives our reproductive impulses, it is the restraint of the plant psukhê in the service of telos which elevates human life in the eyes of Aristotle and, much later, Hegel ${ }^{40}$. Marder argues that by presuming that all life must have telos, or some sort of culminating, transcendent purpose which is apparent to humans, we are not able to approach plant existence on relevant terms.

Returning to the Tribulus thorn lodged in my finger, a traditional botanist might describe this encounter as part of the plant's end-game sexual reproductive strategy perhaps successful (because I did move the seeds a few feet down the road) or unsuccessful (because I threw the seeds onto pavement). Thinking of plant meanings away from reproductive telos, however, we might read this as a rhizomatic ${ }^{41}$ act of reproduction, one which increases number but does not preserve species or self. Alternatively, we can think of the lodged thorn as a communicative or expressive act, perhaps a botanical rejection of a settler body. Perhaps it is a close (too close) push for intimacy, or the taking up of a new home. My aim here is not to explicate exactly what this encounter with Tribulus means for Tribulus, but to demonstrate the imaginative capacities - proper to humans - which we can employ in our vegetal interactions by thinking away from telos.

We can extend this experimentation to archival things: if we expect the materiality of archival things to express a telos which aligns with human expectations and goals, we will be disappointed. When we view archival things as having failed us, through

39 Present-day botany would, of course, challenge the idea that plants do not have a bodily interiority like that of animals. Yet, we continue to understand plants as having no inner psychic life, or at least not a psychic life like that of animals and humans. It is this second kind of interiority which is continually denied to plants.

40 Jeffrey Nealon, Plant Theory: Biopower and Vegetable Life (Stanford, CA: Stanford University Press, 2016), 68.

41 Rather than referring to a botanical rhizome, I refer here to the concept of the "rhizome" which Gilles Deleuze and Felix Guattari describe in A Thousand Plateaus: Capitalism and Schizophrenia. Rhizomatic reproduction could be said to be "anti-genealogical," akin to horizontal gene transfer. See Gilles Deleuze and Felix Guattari: A Thousand Plateaus: Capitalism and Schizophrenia (Minneapolis, MN: University of Minnesota Press, 1987), 11. 
degradation or decomposition, we have fundamentally misunderstood the archival thing, a thing which is not human. Though we may shape these material entities for human purposes, they are material things which change in ways proper to their materiality without regard for our desire to remember and prove - desires which drive the archival institution.

Returning to the Carithers sticky photo assemblage with the lessons of Tribulus, the critical action here is not to glimpse the meaning of the assemblage for the assemblage, but instead to let the assemblage "cut the nets" which separate meaningful from meaningless. What meanings, however wrong they might be, can we imagine if we suspend our insistence that thing-acts are meaningless? I would propose a few options (at least) are available. First, we can think of this assemblage as a suppressive act. In the forming of the assemblage, photo surfaces are submerged into one another and lost to vision-centered creatures such as ourselves. Photographs are without eyes, without the mammalian vision which is given such prominence in our cultures. What does a photo (as a grammatical subject) lose when its image side fades? Second, we can think of this assemblage as an act of reinforcement. By "lumping" themselves together, the constituents of the assemblage stand a better chance of weathering various material conditions and encounters. A notable exception would be the assemblage's encounter with the archivist, which is likely to result in attempts to separate the parts. Perhaps a third reading, then, is that the assemblage is a provocation. When we are frustrated by the photographs, they have provoked some sort of affective meaning within us - no matter how fleeting that affect may be. These markedly anthropomorphic suggestions are themselves provocations, insistences that what is looked upon as a failing object, a frustrating degradation, or a lost document represents the basic condition of the archives and not a set of aberrations. Archival things exist on terms relevant to their materiality, a materiality which might be meaningful but without purpose.

\section{ARCHIVAL ENTROPY}

If the archival thing does not exist for us, and generates meanings which exceed our intentions or utilities, then we can re-frame what we might call the 'decay' or decomposition of Joe Carithers' photographs as a set of events which are as much about the generation of knowledge as its loss. Caitlin DeSilvey suggests we can 'curate decay' and engage decomposition as part of - rather than the opposite of - curation..$^{42}$ DeSilvey notes that, within the context of British heritage studies, the preservation of all historic structures has become untenable. All of England is historic, but not every historic structure can be maintained in perpetuity. Though the logistics of retaining Tudor

${ }^{42}$ Caitlin DeSilvey, Curated Decay: Heritage Beyond Saving (Minneapolis, MN: University of Minnesota Press, 2017). 
mansions are quite different from that of retaining an author's papers, one cannot help but see this as the "backlog and overflow crises" of archives being played in another context. ${ }^{43}$ These crises have prompted new approaches to archiving, including Mark Greene and Dennis Meissner's bold stances on processing, reappraisal, deaccessioning (in the form of More Product Less Process)..$^{44} \mathrm{~A}$ subtle difference between deaccessioning and curating decay, however, is that deaccessioning renders a thing as definitively nonarchival, beyond the archive. By contrast, DeSilvey's notion of curated decay allows a thing to retain its place within the program of remembering. The disintegration of a thing is integrated into heritage practice.

Decay can be understood as a type of entropic arrangement, an expression of the many possible arrangements which are inherent in matter. ${ }^{45}$ With all photographic surfaces facing away from one another, Joe Carithers' photos reveal only one possible arrangement. With enmeshed photo surfaces forming new assemblages, other possible arrangements are revealed and entropy increases. This is not a loss of the "before" photos, but a "release into other states," 46 or a "self-excavation" ${ }^{47}$ which reveals aspects of materiality not visible in earlier states. Photographs which are kept separate from one another are not different, insomuch as they are continually renewed into their material form through maintenance and preservation action. ${ }^{48}$ That is to say, no photograph stays "pristine" on its own: the appearance of stasis or sameness is continually constructed through archival action. Alongside these actions, we continually re-accept the renewed thing as "original" or "authentic." The postmodern refrain of performativity echoes on here: an archival thing is constantly becoming an archival thing. What we regularly describe as conservation or preservation can be reinterpreted as the selective unfolding of material possibilities to create a desired assemblage of vibrant matter.

\footnotetext{
${ }^{43}$ Leonard Rapport's famous polemic on reappraisal and deaccessioning deals very directly with the question of archival overflow. Leonard Rapport, "No Grandfather Clause: Reappraising Accessioned Records," The American Archivist 44, no. 2 (1981): 143-150. Meanwhile, Karen Benedict's reply to Rapport cautions archivists that it is better to never have accessioned a record than to deaccession it later. Karen Benedict, "Invitation to a Bonfire. Reappraisal and Deaccessioning of Records as Collection Management Tools in an Archives: A Reply to Leonard Rapport," American Archivist 47, no. 1 (1984): 43-49.

${ }^{44}$ Mark A. Greene and Dennis Meissner, "More Product, Less Process: Revamping Traditional Archival Processing," The American Archivist 68 (Fall/Winter 2005): 208-263; Mark A. Greene, "I've Deaccessioned and Lived to Tell About It: Confessions of an Unrepentant Reappraiser," Archival Issues 30, no. 1 (2006): 7-22.

${ }^{45}$ DeSilvey, 10.

${ }^{46}$ Ibid., 3.

${ }^{47}$ Ibid., 19.

${ }^{48} \mathrm{Ibid} ., 168$.
} 
In pivoting towards the material, however, we need not forget about the psychic, social, and historical valences of archival things. When Bennett sees a puddle-assemblage strewn with "litter" and a bird carcass, she is careful to note that her interpretation is also part of that assemblage, and so is the scholarship she has read to form that interpretation. For archivists, this is key: the social is forever part of the material. DeSilvey's case study of Mullion Harbor demonstrates this clearly. The Harbor is perpetually demolished by seasonal storms and the receding coast, then perpetually reinforced and partially re-built. During and in between, the Harbor is a topic of ongoing conversation. The Harbor's history is again and again re-told and its importance is argued again and again. The Harbor is linked to social meanings and its periodic imperilment creates a sudden attention to the materiality of something which is otherwise treated a physical substrate for psychological meaning. In these moments, DeSilvey offers that:

If memory is understood not as something that is deposited within material containers for safekeeping but as something that is "ignited in dialogue between mind and matter," then it does not necessarily need to rely on a stable material form for its expression...It may be that in some circumstances a state of gradual decay provides more opportunity for memory making, and more potential points of engagement and interpretation, than the alternative. ${ }^{49}$

The instability of the harbor in fact makes memory more possible by continually calling residents to action: to rebuild, to reinforce, to debate the harbor's future. People who strongly disagree about the Harbor's future - and even those who do not believe it should be preserved - carry heavy pavers from the ocean after a storm to re-constitute the Harbor's structure in a "provisional and situated response." ${ }^{50}$ DeSilvey notes that it is when a historic structure as seen as stable and out-of-danger that it becomes most at risk of being forgotten.

As the Harbor demonstrates, the lines of connection between matter and memory are not linear, but wend through affect to survive destruction, decomposition, and death. Hariz Halilovich's writing on Bosnian oral histories shows how the destruction of archival things - and not their preservation - becomes intertwined with memory. ${ }^{51}$ Halilovich recounts the testimony of "Stana, a Sarajevan who lived near [the Bosnian national archives]" prior to their destruction by fire during the Bosnian war. ${ }^{52}$ Although

\footnotetext{
49 Ibid., 14-15.

50 lbid., 68.

${ }^{51}$ Hariz Halilovich, "Re-Imaging and Re-Imagining the Past after 'Memoricide': Intimate Archives as Inscribed Memories of the Missing," Archival Science 16, no. 1 (2016): 77-92. https://doi.org/10.1007/s10502-015-9258-0.

52 lbid., 84.
} 
Stana had fled to Germany before the conflagration, in an interview she recalls the event as though she had viewed it from her home. For Stana, the destruction of the archival thing as an event becomes a temporal location from which she remembers. Destruction of the archive, not continuation, generates memory in this instance.

Most archivists, I suspect, would describe decaying archival things as "problems." Indeed, a reader of an earlier version of this essay expressed profound concern about recognizing Carithers' "photo assemblage" as anything other than a problem or - as they put it - the failure of the archivists responsible. The word "problem" became part of the Middle English lexicon by way of Middle French, and more distantly from the Greek morphemes pro- (forward) and ballo+ma (a throw), with balloma deriving from the verb ballo. ${ }^{53}$ While ballo can certainly mean "to throw," its transitivity is not fixed by the verb root itself. Ballo can be conjugated to mean "I throw," "I let fall," "I strike," "I place," or even "I fall." ${ }^{54}$ Ballo is used to describe a body in motion, though who is moving and who is moved depends on grammatical context.

The ambiguity of this root morpheme brings to mind Linda Tuhiwai-Smith's account of map-making as a colonial apparatus. According to Tuhiwai-Smith, anything within British colonial territories which did not conform to extant imperial knowledge was disciplined as a problem. ${ }^{55}$ The indigenous person who is beyond the border of the colony, within terra nullius, is transformed into a problem through the map. Terra nullius should be empty space, but the indigenous body in that space troubles the map's power to name and describe. The border works in tandem with the line - the European conception of distance which permits bodies to be distant from nature, or from the materiality of government, while still being under its influence. ${ }^{56}$ In drawing the colonial border as the limit of existence, the empire names the indigenous body as a problem and through that naming witnesses the limits of its power: I place / I fall. In drawing the border - the limit of its power - and naming the inhabited land beyond that border as "empty," the empire "archivalizes" 57 the fear of its own unstable power. Likewise, by problematizing the thingassemblage which seems to be made of two photographs, the archivist draws a border to define the archival from the non-archival. The non-archival matter and troubling assemblages which "clutter" archival spaces, however, demonstrate the limits of our

${ }^{53}$ Oxford English Dictionary Online, s.v. "problem," accessed January 22, 2018.

${ }^{54}$ Richard Cunliffe, Jr., " $\beta \alpha \dot{\lambda} \lambda \lambda \omega$," in A Lexicon of the Homeric Dialect: Expanded Edition (Norman, OK: University of Oklahoma Press, 1963).

${ }^{55}$ Linda Tuhiwai-Smith, Decolonizing Methodologies: Research \& Indigenous Peoples (London, UK: Zed Books, 2012) 71.

${ }^{56}$ Ibid., 58.

57 "Archivalization" is a neologism introduced by Jacques Derrida to describe the psychic maneuvers by which the unbearable is repressed, transformed, and then externalized into archival things. See Jacques Derrida, Archive Fever: A Freudian Impression (Minneapolis, MN: University of Minnesota Press, 1994). 
powers: I place / I fall. The archivist, who is decaying and decomposing alongside the assemblage, then seeks a way to forget or resolve what they foresee by deaccessioning the assemblage or attempting to mechanically undo it. Where design fails to constrain material possibilities, affect emerges. Tom Roberts cites a coffee strainer turned choking hazard as an example of an affect-provoking thing. ${ }^{58}$ If we balk at the idea of "sticky photographs" representing meaningful material engagements disconnected from human interests, it is perhaps because we have glimpsed our own mortality and forgetting in the archives - in an institution which alludes to the persistence of existence and memory. We place the assemblage outside of the archives, as a "problem" through deaccession or destruction, and thereby fall on our own mortality.

Curating decay and imagining the vibrant archives are practices which work against these ontological borders. Yet, curating decay is not simply allowing everything to "fall apart" without any social intervention - it is not setting the archive on fire with no forethought. Curating - and archiving - with decay in mind instead asks us to work with the entire "lifecycle" of a thing and to allow many meanings to emerge through its "selfexcavations" and new states. As a heritage site falls apart, we are forced to discuss the political regimes which built them in the first place, the economic and social collapses which led to their current states, and which decaying buildings receive attention and which do not. We begin to notice which plants overtake the crumbling structure, both in the vertical and horizontal. We attend to the species and abiotic entities (rivers, hillsides, wind patterns, sandstorms) which were displaced or redirected to create the structure. These are specific, contextualized conversations. Many of Joe Carithers' photographs did not adhere to one another. In this context, it seems possible to retain the sticky assemblage as evidence of material possibilities inherent - but unexpressed - in the other photographs. Bethany Nowviskie suggests a similar approach to digital records when she advocates for the "graceful degradation" of files, formats, and platforms. ${ }^{59}$ Graceful degredation, like the curation of decay, minds the limits and lifespans of matter, and advocates for a better understanding of ephemerality. Not all records created must, or should, or were intended to, last forever - and none can. This is not a cautionary tale about archival practice, but a window into archival materialities which are overlooked in favor of extractable textual and pictorial information.

In these conversations, the porous boundaries between a "proper" heritage site or archival thing and undesirable "stuff" also come to the fore. The Murphey Building Company ledgers, referenced in the opening to this essay, were caked in thick dust. ${ }^{60}$ Moving our focus back and forth between material and social valences, we see the dust

\footnotetext{
58 Roberts, 2524.

${ }^{59}$ Nowviskie, i12.

60 John W. Murphey Building Company Records, 1919-1972 (MS 603), Special Collections, University of Arizona Libraries.
} 
as something different from the ledger but not entirely meaningless. It is non-textual, but it is the physical trace of other things we might have archived. At the same time, it is evidence that, "nothing really ever goes away." ${ }^{61}$ Microscopically intertwined with the paper fibers of the ledgers and the tissue of the leather binding, dust troubles the line between the archival thing and non-archival interlopers. I am not suggesting that the dust be described per DACS, cataloged, and served to researchers - in this case, anyway - but instead that there is no reason to exclude the dust from our intellectual endeavors. When we displace dust from an archival thing, it is placed onto another thing. It can be moved or trapped, but it is never fully eliminated..$^{62}$ Dust might be a haunting or a taunting, but it is not meaningless. Engaging with the meaning of decay does not guarantee forgetting, nor does understanding matter as "vibrant" deny the sociocultural meanings rendered through and alongside matter. ${ }^{63}$ Although a thing's vibrancy is not by definition a resource or provocation for humans, the configuration of its vibrancy - its possibilities - can unfold towards us.

\section{PRESERVING \& MOURNING}

For Jacques Derrida, the archive - and, I will add, the archives - is only possible because loss is possible. If we could remember forever without fault or failure, the archives would be unnecessary. Throughout this essay, I have tracked the ways that the matter of the archives mimics' Derrida's assertions. The archives comes to importance through the possibility of decomposition and re-composition of archival things. Thus, the Anthropocene is not itself a change in the materiality of the archives, but a diagnosis - a point at which we recognize capacities which archival things have always held, and the loss promised by presence. Within discussions of the Anthropocene, loss of life (bodily or social) is often termed 'extinction,' and it is the possible extinction of the archives (and its stewards, and its users, and those reflected in its holdings) which the Anthropocene threatens to bring to pass. "Extinction," in the vocabulary of biodiversity, insinuates the loss of a potential genetic resource more than the loss of individual lives. A fear of extinction is, in part at least, a fear of losing what might be valuable in the future - a very archival feeling. However, Audra Mitchell highlights that extinction is also a proliferation of forms, through which new species emerge and through which humans multiply a

${ }^{61}$ Carolyn Steedman, Dust (Manchester, UK: Manchester University Press, 2001), 164.

62 Michael Marder's object lesson on dust offers psychoanalytic considerations of the futility and importance of dusting. See Michael Marder, Dust (New York: Bloomsbury Publishing, 2016).

${ }^{63}$ Within heritage studies in particular, Bennett's project of vibrant matter has been charged with ignoring the social aspects of matter, at least in part. See Nadia Bartolini, "The Politics of Vibrant Matter: Consistency, Containment and the Concrete of Mussolini's Bunker," Journal of Material Culture 20, no. 2 (2015): 191-210. 
species' image (think dinosaurs). ${ }^{64}$ Understanding death as part of survival, Donna Haraway reminds us that "renewed generative flourishing cannot grow from myths of immortality or failure to become-with the dead and extinct." ${ }^{65}$ Haraway hopes for a postAnthropocene era wherein we unbound "human" as a sacred category, become with our planetary others (much as Carithers' photos became with humidity and time), and carefully trace, reflect upon, and act mindful of the incalculable "I"s invoked in "we." The Anthropocene prompts us to ask what (and who) else the archives might be and might look like in future eras of planetary time.

Returning to the question I posed earlier, how do we cope with - and perhaps act upon - extinction and the archives? I suggest, as a start, that we can mourn the archives. We can recognize that the materiality which makes the archives possible is also the promise of its decay. Material decay is a bodily change in an archives which triggers a loss of memory and identity for humans. Archival things are the transitional or memorial objects $^{66}$ through which we mediate our grief about and connection to the past, but they are also entities of a certain kind, dying a certain kind of death within our perceptions. The archives does not evade loss. As photo surfaces fuse, fade, and crack apart we might try holding those photos against ourselves in an embrace and experience them in nonvisual ways. Absurd as it sounds, this is a step towards understanding the psychic life of the archives and archivist. Through this "affective experimentation" we may find that more than mourning the "things," we are mourning the archivist's power and the promise of "information resources." In mourning, we will understand ourselves and our archives as part of processes of proliferation, decay, forgetting, and remembering, ad infinitum. As the archives dies and as we mourn, space opens for new ways of remembering and transmitting to emerge. While loss is the condition which makes the archives possible, the archives is not the guaranteed outcome of that condition. For archivists, the Anthropocene can be a time of radical re-imagination and experimentation, away from the promises of preservation and the hopes of an eternal record. If there are no archives, what is there? If we are not archivists, who are we? Though not a call to burn the archives, I suggest that the Anthropocene is something of a matchbook on our collective table, opening outwardly with possibilities for changes in state, rate, and kind.

\footnotetext{
${ }^{64}$ Audra Mitchell, "Beyond Biodiversity and Species: Problematizing Extinction," Theory, Culture, and Society 33, no. 5 (2016) 23-42.

65 Donna Haraway, “Chthulucene: Making Kin,” Environmental Humanities 6 (2015): 159-165.

${ }^{66}$ For a discussion on memorial objects, mourning, and melancholia, see: Margaret Gibson, “Melancholy Objects," Mortality 9, no. 4 (2004): 285-299.
} 


\section{ACKNOWLEDGEMENTS}

I would like to thank Dr. Jennifer Jenkins for her generous guidance and support while I researched and struggled with the ideas put forward in this essay. An early version of this paper was presented as part of the "Living Matters" seminar of the 2018 American Comparative Literature Association annual meeting. My thanks to the organizers and participants of "Living Matters" for their insightful feedback and encouragement. Thank you also to Harrison Apple for listening and reading with patience and imagination. Finally, thank you to the Tribulus pods ever in my foot, my hand, and my mind. 


\section{BIBLIOGRAPHY}

Acker, Amelia. "How Cells Became Records: Standardization and Infrastructure in Tissue Culture." Archival Science 15, no. 1 (2015): 1-24.

Bailey, Jefferson. "Disrespect des Fonds: Rethinking Arrangement and Description in Born-Digital Archives." Archives Journal (Summer 2013). http://www.archivejournal.net/issue/3/archives-remixed/disrespect-des-fondsrethinking-arrangement-and-description-in-born-digital-archives/.

Barad, Karen. "TransMaterialities: Trans*/Matter/Realities and Queer Political Imaginings." GLQ: A Journal of Gay and Lesbian Studies 21, nos. 2-3 (2015): 387422.

Bauman, Whitney. "Climate Weirding and Queering Nature: Getting Beyond the Anthropocene." Religions 6, no. 2 (2015): 742-754.

Bartolini, Nadia. "The Politics of Vibrant Matter: Consistency, Containment and the Concrete of Mussolini's Bunker." Journal of Material Culture 20, no. 2 (2015): 191-210.

Benedict, Karen. "Invitation to a Bonfire. Reappraisal and Deaccessioning of Records as Collection Management Tools in an Archives: A Reply to Leonard Rapport." The American Archivist 47, no. 1 (1984): 43-49.

Bennett, Jane. Vibrant Matter: A Political Ecology of Things. Durham, NC: Duke University Press, 2010.

"Bibliography." Literary and Critical Plant Studies Network. https://plants.sites.arizona.edu/content/8.

Carithers, Joe. Papers (MS 600). Special Collections, University of Arizona Libraries.

Cifor, Marika. "Stains and Remains: Liveliness, Materiality, and the Archival Lives of Queer Bodies." Australian Feminist Studies 32, no. $91-92$ (2017): 5-21.

- - . "Affect Relations: Introducing Affect Theory to Archival Discourse." Archival Science 16, no. 1 (2016): 7-31.

Conway, Paul. "Digital Transformations and the Archival Nature of Surrogates." Archival Science 16, no. 1 (2015): 51-69.

Cunliffe, Richard, Jr. " $\beta \alpha \dot{\lambda} \lambda \lambda \omega$ " in A Lexicon of the Homeric Dialect: Expanded Edition. Norman, OK: University of Oklahoma Press. 1963.

Cvetkovich, Ann. An Archive of Feelings: Trauma, Sexuality, and Lesbian Public Cultures. Durham, NC: Duke University Press, 2003. 
Deleuze, Gilles and Felix Guattari. A Thousand Plateaus: Capitalism and Schizophrenia. Minneapolis, MN: University of Minnesota Press, 1987.

Derrida, Jacques. Archive Fever: A Freudian Impression. Minneapolis, MN: University of Minnesota Press, 1994.

DeSilvey, Caitlin. Curated Decay: Heritage Beyond Saving. Minneapolis, MN: University of Minnesota Press, 2017.

Dever, Maryanne. "Provocations on the Pleasure of Archived Paper." Archives and Manuscripts 41, no. 3 (2013): 173-182.

Duranti, Luciana. "The Concept of Appraisal and Archival Theory." The American Archivist 57, no. 2 (1994): 328-344.

Gibson, Margaret. "Melancholy Objects." Mortality 9, no. 4 (2004): 285-299.

Goldman, Ben. "It's Not Easy Being Green(e): Digital Preservation in the Age of Climate Change." Archival Values: Essays in Honor of Mark Greene. Chicago, IL: Society of American Archivists, Forthcoming. Accessed from: https://scholarsphere.psu.edu/concern/generic_works/bvq27zn11p.

Greene, Mark A. "I've Deaccessioned and Lived to Tell About It: Confessions of an Unrepentant Reappraiser." Archival Issues 30, no. 1 (2006): 7-22.

Greene, Mark A. and Dennis Meissner. "More Product, Less Process: Revamping Traditional Archival Processing." The American Archivist 68 (Fall/Winter 2005): 208-263.

Halilovich, Hariz. "Re-imaging and Re-imagining the Past after 'Memoricide': Intimate Archives as Inscribed Memories of the Missing." Archival Science 16, no. 1 (2016): 77-92.

Hall, Matthew. Plants as Persons: A Philosophical Botany. Albany, NY: SUNY Press, 2011.

Haraway, Donna. "Chthulucene: Making Kin." Environmental Humanities 6 (2015): 156165.

- - When Species Meet. Minneapolis, MN: University of Minnesota Press, 2008.

Lomberg, Bjorn. The Skeptical Environmentalist: Measuring the Real Estate of the World. Cambridge, UK: Cambridge University Press, 2004.

Marder, Michael. "On Lack and Plenitude in the Vegetal World." Keynote address, Plantarium: Re-Imagining Green Futures, Linköping University, Sweden, June 1, 2017. http://www.totuusradio.fi/wordpress/wp-content/uploads/2017/10/ marder075.mp3. 
-- - Dust. New York: Bloomsbury Publishing, 2016.

- - . Plant-Thinking: A Philosophy of Vegetal Life. New York: Columbia University Press, 2013.

Marder, Michael and Mathilde Roussel. The Philosopher's Plant: An Intellectual Herbarium. New York: Columbia University Press, 2014.

Mitchell, Audra. "Beyond Biodiversity and Species: Problematizing Extinction." Theory, Culture, and Society 33, no. 5 (2016): 23-42.

Murphey, John W. Building Company. Papers (MS 603). Special Collections, University of Arizona Libraries.

Nealon, Jeffrey. Plant Theory: Biopower and Vegetable Life. Stanford, CA: Stanford University Press, 2016.

Nesmith, Tom. "The Concept of Societal Provenance and Records of Nineteenth-Century Aboriginal-European Relations in Western Canada: Implications for Archival Theory and Practice." Archival Science 6, nos. 3-4 (2006): 351-360.

Nowviskie, Bethany. "Digital Humanities in the Anthropocene." Digital Scholarship in the Humanities 30, no. 1 (2015): i4-i15.

Oxford English Dictionary Online, s.v. "problem," accessed January 22, 2018.

Rapport, Leonard. "No Grandfather Clause: Reappraising Accessioned Records," The American Archivist 44, no. 2 (1981): 143-150.

Rekrut, Ala. "Matters of Substance: Materiality and Meaning in Historical Records and their Digital Images." Archives and Manuscripts 42, no. 3 (2014): 238-247.

Roberts, Tom. "From 'New Materialism' to 'Machinic Assemblages': Agency and Affect in IKEA." Environment and Planning A 44, no. 10 (2012): 2512-2529.

Society of American Archivists. "What are Archives?" 2015. https://www2.archivists.org/about-archives.

Steedman, Carolyn. Dust. Manchester, UK: University of Manchester Press, 2011.

Tansey, Eira. "Archival Adaptation to Climate Change." Sustainability: Science, Practice and Policy 11, no. 2 (2015): 45-56.

Tuhiwai-Smith, Linda. Decolonizing Methodologies: Research \& Indigenous Peoples. London, UK: Zed Books, 2012.

Usher, Phillip John. "Untranslating the Anthropocene." Diacritics 44, no. 3 (2016): 56-77.

Veerkamp, Anthony. "Preservation in a Changing Climate: Time to Pick Up the Tab." Forum Jounral 29, no. 4 (2015): 9-18. 
Vestberg, Nina Lager. “Archival Value." Photographies 1, no. 1 (2008): 49-65.

Vieira, Patricia, Monica Gagliano, and John Ryan (eds.). The Language of Plants: Science, Philosophy, and Literature. Minneapolis, MN: University of Minnesota Press, 2017.

Wolfe, Mark. "Beyond 'Green Buildings': Exploring the Effects of Jevon's Paradox on the Sustainability of Archival Practices." Archival Science 12, no. 1 (2012): 35-50. 